Please do not remove this page

RMIT

UNIVERSITY

\title{
Social Enterprises and the Performance Advantages of a Vincentian Marketing Orientation
}

Miles, Morgan; Verreynne, Martie-Louise; Luke, Belinda

https://researchrepository.rmit.edu.au/esploro/outputs/9921861700301341/filesAndLinks?institution=61RMIT_INST\&index=null

Miles, M., Verreynne, M.-L., \& Luke, B. (2014). Social Enterprises and the Performance Advantages of a Vincentian Marketing Orientation. Journal of Business Ethics, 123(4), 549-556.

https://doi.org/10.1007/s10551-013-2009-3

Document Version: Accepted Manuscript

Published Version: https://doi.org/10.1007/s10551-013-2009-3

Repository homepage: https://researchrepository.rmit.edu.au

(c) Springer Science+Business Media Dordrecht 2013

Downloaded On 2023/04/26 16:58:37 +1000

Please do not remove this page 


\title{
Social Enterprises and the Performance Advantages of A Vincentian Marketing Orientation
}

Submission to the $19^{\text {th }}$ Annual International Conference Promoting Business Ethics Conference's Special Edition of the Journal of Business Ethics

\author{
Morgan P. Miles* \\ School of Management, \\ University of Tasmania, Locked Bag 1351, \\ Launceston TAS 7250 \\ Australia \\ T 61363243928 |F 61363243100 \\ Morgan.miles@utas.edu.au \\ Martie-Louise Verreynne \\ UQ Business School \\ University of Queensland, St Lucia \\ Australia \\ m.verreynne@business.uq.edu.au \\ Belinda Luke \\ Business School \\ Queensland University of Technology \\ Brisbane \\ Australia \\ b.luke@qut.edu.au \\ *: Contact author
}




\section{Social Enterprises and the Performance Advantages of a Vincentian Marketing Orientation}

"Vincent saw his business dealings as a public trust. Managers trained in the Vincentian tradition must not only keep their eye on the profit line but on the effects their company policies have on the marginalized of society," (Bowes 1998: 1666).

Social enterprises (SE) are organizations with an overarching core social mission funded through market-based initiatives (see Kerlin 2006). They exist to serve their beneficiaries and are increasingly being relied upon to provide essential social services as government services decline. For example, in the United Kingdom (UK), Bennett (2008) reports that voluntary organizations and social enterprises have become major providers of numerous social welfare services previously supplied by the state. Similar conditions exist for social services in most nations, and, in many cases, some form of social enterprise is attempting to "fill the gaps" left as government social services decline.

Social enterprises are hybrid organizations established for a social purpose, using a for-profit business model to generate the financial resources needed to support their social missions. As unmet social needs become more critical, social enterprises are seeking to become more efficient and effective in their operations and strategies to fulfil their missions. Adding to the complexity, social enterprises are often evaluated by their stakeholders from a multiple bottom line perspective - that is how the social enterprise performs in economic, social, and environmental terms (Cornelius, Todres, Janjuha-Jivraj, Woods, and Wallace, 2007). These pressures are forcing social enterprises to explore the development of new capabilities by adopting processes, techniques, tactics, and strategies from the private sector to enhance overall performance.

In Paris during the 1600 's, St. Vincent de Paul founded the Ladies of Charity that leveraged business to serve the needs of the poor by combining the tools of commerce with 
the values of Christianity (see for example, McKenna 1997; Bowes 1998). Bowes (1998: 1666) suggests that St. Vincent developed a "theology of business ethics," driven by an organizational wide philosophy that focuses on helping the poor while remaining economically viable. St. Vincent's drive to more efficiently and effectively serve the poor resulted in early adoption of modern management practices and the creation of various social enterprises.

Marketing is one such area of business that offers promise for more efficient and effective management of social enterprises. An organizational-wide adoption of a marketing orientation has been linked to enhanced performance over a wide variety of contexts (Jaworski and Kohli 1993; Avlonitis and Gounaris 1997; Kirca, Jayachandran and Bearden 2005) including non-profits (Balabanis, Stables, and Phillips 1997; Gainer and Padanyi 2002; Kara, Spillan, and DeShields 2004; Mottner and Ford 2005). Bennett (2008) applied marketing and sales management techniques to the context of social enterprises contracting with the government to provide social services in the UK and found that strategic account management can enhance satisfaction and funding for the social enterprise.

Marketing, as a discipline, has a tradition of working toward the solution of social problems. For example, Kotler and Levy (1969) formally introduced social marketing by "broadening the concept of marketing" to include applying tools and techniques such as segmentation, target marketing, and positioning strategies to non-business issues as diverse as political candidates, social goods like education, and social causes such as the Salvation Army. As with St. Vincent's work with the poor, marketing, as an organizational philosophy, attempts to address human needs. While tremendous advances in social marketing and related areas such as environmental marketing have occurred since the 1960's (see, for example Polonsky 2011), much work still remains to be done on leveraging marketing to solve complex social problems (Maignan and Ferrell 2004). 
This study extends previous work by Miles, Verreynne, Luke, Eversole, and Barraket (Forthcoming) on the application of Vincentian social values towards an entrepreneurial business philosophy or orientation. It proposes the adoption of a Vincentian-based marketing orientation for social enterprises that explicitly addresses the unique mandate of having both an overarching social mission (driven by an ethical and moral imperative to serve the poor) coupled with the need to be economically viable. The notion of economic viability is particularly relevant to ensuring financial sustainability, such that social enterprises are able to provide viable solutions to long-standing social problems. The adoption of a Vincentian marketing orientation (VMO) by a social enterprise is an organization wide philosophy that is consistent with the tenets of a Vincentian theory of business ethics as proposed by Bowes (1998). Flanagan, Fleckenstein, Primeaux, Schoaf, and Werhane (2008: 1) note that "Vincent DePaul is hailed as the Roman Catholic Church's "patron saint of charity," but what he did was more than mobilize charity; he matched it with justice. He sought not to do merely patchwork, but offered some long-term viable solutions."

A Vincentian perspective is conceptualized as a broad ethical framework centred on efficiently and effectively serving the poor and needy of society. In the context of the present study, it does not suggest any religious affiliation but rather a philosophy of helping the less fortunate. Essentially, it is the adoption of a set of organizational values that impacts the social enterprise's strategy and tactics including (1) a focus on serving the poor and marginalized of society; (2) efficiency and effectiveness of business operations; and (3) an appreciation for value-driven management.

These Vincentian values have been institutionalized as discussed by Ferrari and Cowman (2004) in the case of DePaul University. These values refer to the University's explicit focus on serving the poor and disenfranchised through volunteer and community service programs and respect for human dignity. As institutional values, these concepts have been adopted by social enterprises to varying extents; however, research examining the extent 
to which such values are incorporated and institutionalised within social enterprises remains scant (see for example Nicholls 2009; 2010).

\section{Purpose}

The primary purposes of this study are (1) to determine if social enterprises that adopt a Vincentian marketing orientation (VMO) are customer-centric by putting the wellbeing of the beneficiaries first; (2) to determine if social enterprises that adopt a VMO exhibit enhanced economic, social, and environmental performance; and (3) to determine if social enterprises that adopt a VMO consider value creation a long-term multi-dimensional process.

\section{Marketing orientation}

A marketing orientation is the adoption by an organization of a customer-centric concept of marketing (see Borch, 1957; Felton, 1959; Keith, 1959; 1960) that transforms the heuristics of marketing strategy from a focus on selling what the firm produces to producing what customers want and need. The marketing concept is a set of maxims that operationalize the official definition of marketing adopted by the American Marketing Association and provide guidance to strategic and tactical marketing decision making (Darroch, Miles, Jardine, and Cooke, 2004).

Traditionally, the marketing concept has rested upon four axioms: "(1) customer orientation, (2) customer satisfaction, (3) coordinated or integrated marketing and (4) a focus on profitability" (Miles and Arnold 1991: 50). A marketing orientation is the adoption and implementation of the marketing concept by an organization (Foxall 1984; Perreault, Cannon, and McCarthy 2008); however, as the definition and scope of marketing changes to reflect the changing social, technological, economic, political, and environmental realities, so must the marketing orientation adapt. As such, a marketing orientation must be dynamic, flexible, and adaptable to new contexts such as social enterprises. 
Redefining activities such as political campaigns, social causes, and fundraising for charities to be marketing occurred due to the work of marketing scholars such as Kotler and Levy (1969) and Lazer (1969) in response to their observations that marketing could help when applied in a social context. Since its 1935 definition of marketing, the American Marketing Association (AMA) has adopted three newer versions, with the 2007 definition being the most recent (Sheth and Uslay 2007). The 2007 definition defines marketing to be "the activity, set of institutions, and processes for creating, communicating, delivering, and exchanging offerings that have value for customers, clients, partners, and society at large (www.marketingpower.com)."

The 2007 definition of marketing explicitly integrates the notion of value creation for society as a marketing function, providing a fundamental conceptual foundation for the development of the Vincentian marketing orientation.

\section{Social enterprise and marketing}

Social enterprises, being organizations with a predominantly social purpose that trade to support their operations, face multiple objectives and challenges (Barraket, Collyer, O’Connor, and Anderson, 2010). Aiming to address long-standing social problems in new and innovative ways, SEs must balance a social mission with business capabilities to establish financially sustainable operations. Managing these often competing interests is challenging with different SEs having different priorities and emphasis within their business operations.

Research explicitly addressing marketing in the context of social enterprise has been minimal (see Shaw, 2004). Notable exceptions include Balabanis et al.'s (1997) seminal work on the marketing orientations of British charities; Kara et al.'s (2004) work on the marketing orientation of non-profits in the U.S.; Bennett's (2008) study of strategic account management and social enterprise in the UK; and Zhou, Chao, and Huang's (2009) work on marketing orientation and blood banks in China. 
The present study extends Balabanis et al. (1997) and Kara et al.’s (2004) work by developing a marketing orientation for social enterprise as an organizational wide philosophy of business that reflects both an organizational focus on creating value for the beneficiary/customer and the necessity of the organization to create value for the beneficiaries and funders. Marketing oriented SEs (1) put the interests of the beneficiary first and foremost, while concurrently generating value for their donors, and external stakeholders; (2) have economic, social, and environmental sustainability as a core objective; and (3) look at creating value for their beneficiaries, donors and other stakeholders as a long-term process (see Kara et al., 2004; Kolhi et al., 1993; Vazquez, Alvarez, and Santos, 2002; Zhou et al., 2009).

These works, integrated with the AMA's 2007 definition of marketing, and Vincentian principles of ethics provide the basis for a conceptual framework of how valuedriven social enterprises might adopt the marketing concept. Like the traditional marketing concept, the social enterprise marketing concept has, at its core, creating value for its "customers"- the beneficiaries of the social enterprise. We therefore propose that P1: Social enterprises that have adopted a Vincentian marketing orientation tend to put the wellbeing of the beneficiaries first in their business decisions.

Social enterprises tend to face scrutiny from the community and other stakeholders and, therefore, attempt to be more socially responsive. While the traditional marketing concept suggests that profits are derived from a long-term relationship with the customer, a Vincentian marketing orientation suggests that value for the beneficiaries must typically be created in a socially, environmentally, and economically sustainable manner to meet the diverse demands from various stakeholders. The challenging nature of performance measurement for non-profits in general and SEs in particular has received wide recognition (Barman, 2007). Moss-Kanter and Summers (2001) argue that the test for non-profits should 
be different as they are defined around their missions or services to society. A triple bottom line approach to sustainability provides a framework to do this and measures performance in three areas, namely financial, social, and environmental (Placet, Anderson, and Fowler 2005; Mish and Scammon 2010). Therefore,

P2: Social enterprises that have adopted the Vincentian marketing orientation tend to consider all three dimensions of sustainability in the creation of value for the beneficiaries - economic, social and environmental.

Also, in a similar fashion to traditional enterprise, SEs seek to create satisfaction for beneficiaries but, often, over the long-term and through mechanisms such as training and education. Therefore,

P3: Social enterprises that have adopted the Vincentian marketing orientation tend to consider the creation of value for the beneficiaries and stakeholders as a long-term and multi-dimensional process.

\section{Research method}

The study is based in Australia and extends the work on SEs by Barraket et al. (2010), Eversole and Eastley (2011), and Miles et al. (Forthcoming) by collecting survey data on SE business orientations and organizational performance. Scales adapted from the business literature and augmented with social enterprise dimensions were subject to preliminarily assessment by SE practitioners and pre-tested in a pilot study. Surveys were then administered to a non-random judgement sample of 375 SEs in Tasmania and Queensland in 2011 with the respondents being requested to forward the survey to other social enterprises using a snowball process. SEs supported by the St. Vincent de Paul Society in Australia and other Christian organizations were neither explicitly included nor excluded in the sample but were part of the judgement sample that included co-operatives, fair trade organisations, charitable business ventures, community enterprises, disability enterprises, community development finance institutions, and intermediate labour market companies. 
Items that purport to capture the domain of the Vincentian marketing orientation for social enterprises are listed with means and standard deviations, in Table 1. The scale attempted to capture Vincentian business principles as summarized from Bowes (1998), Flanagan, Fleckenstein, Primeaux, Schoaf, and Werhane (2008), and McKenna (1997) and MARKOR's hypothetical domain by adapting items representing marketing: (1) generation; (2) dissemination; and (3) responsiveness (see Jaworski and Kohli 1993; Kara et al., 2004; Kolhi et al., 1993; Vazquez et al., 2002; Zhou et al., 2009). The items attempt to reflect the multi-dimensional objectives faced by social enterprise executives as described in the Ethos of the St. Vincent de Paul Society in Australia (St. Vincent de Paul Society, 2004).

\section{Table 1 about here}

The 18-item Vincentian marketing orientation scale exhibited a coefficient alpha of .866 , indicating a reliable measure of the construct (exceeding Nunnally's (1978) minimum for a reliable scale). Validity was assessed using maximum-likelihood factor analysis and one factor emerged accounting for over thirty-one percent of variance, suggesting convergent validity.

Social performance is the mission of all social enterprises. The domain of the social performance construct was captured by measuring (1) satisfaction of the donors and beneficiaries; and (2) advocacy for beneficiaries. The eight-item scale developed and used in Miles et al. (Forthcoming) exhibited a coefficient alpha of .733, exceeding Nunnally's (1978) criteria for the development of a reliable scale, and is reported in Table 2. Likewise, economic performance is needed for the social enterprise to operate sustainably, providing services to its beneficiaries on a continuing basis. A six-item scale first reported in Miles et al. (Forthcoming) is used for this measure and illustrated in Table 3. To capture the third dimension of social responsibility a one item metric is used to measure environmental 
sustainability (for more on the usefulness of one item measures see Bergkvist and Rossiter, 2007).

\section{Tables 2 and 3 about here}

A scale that purports to measure the long-term value creation performance of social enterprise was derived from the writings of Bowes (1998), Flanagan et al. (2008), and McKenna (1997) that suggest St. Vincent's core outreach to the poor included (1) actions driven by ethical and moral principles; (2) focus on helping the poor help themselves; (3) constant consideration of how actions impact equity and justice; (4) empathy for the needy; and (5) valuing the long-term benefits of education and training to help improve the lives of the poor. Using items that capture these five dimensions, a scale was developed to be a more conceptually consistent and psychometrically sound measure and exhibited a coefficient alpha of .737, exceeding Nunnally's (1978) criteria .70 for scale development. This longterm value creation scale was assessed using maximum likelihood factor analysis as a psychometric check, exhibiting one factor accounting for 50 percent of the variance. The long-term value creation scale items are illustrated in Table 4.

\section{$\underline{\text { Table } 4 \text { about here }}$}

Approximately 375 social enterprises were directly contacted by e-mail with 85 surveys completed on SurveyMonkey resulting in a nominal response rate of 23 per cent. The SE executive recipients were requested to forward the survey to other SEs using a snowball survey technique; therefore, the actual response rate is unknown.

\section{Findings}

Support for the propositions was assessed using two techniques: (1) correlation analysis; and (2) one-way ANOVA. Social enterprises that were considered to exhibit a VMO were those with a marketing orientation score above the mean score of 3.81 (range of 
2.61 to 4.78 , standard deviation of .434). The findings illustrate the performance advantages of a Vincentian marketing orientation for social enterprises with a significant and positive relationship identified between a VMO and a focus on meeting the needs of the poor (correlations of $.492, \mathrm{p}=.00$ ), supporting Proposition 1. Likewise, additional support for Proposition 1 is indicated by the significant differences between SEs that exhibited a VMO and those that did not $(\mathrm{p}=.003)$. Proposition 2 also enjoyed support with a significant and positive relationships identified between the Vincentian marketing orientation and social performance (correlations of $.659, \mathrm{p}=.00$ ), economic performance (correlation of $.334 \mathrm{p}=$ .027 ), and environmental performance (correlation of .368 $\mathrm{p}=.01$ ) with significant differences between SEs that exhibited a VMO and those that did not in social performance $(\mathrm{p}=.006)$, economic performance $(\mathrm{p}=.025)$, and environmental performance $(\mathrm{p}=.001)$. The finding also identified a significant and positive relationship between a Vincentian marketing orientation and the long-term value creation performance of social enterprise (correlation of $.672, \mathrm{p}=.000$ ) and significant differences between social enterprises that exhibited a VMO and those who did not $(\mathrm{p}=.001)$ in creating long-term value for beneficiaries, supporting Proposition 3. Table 5 summarizes the results of the correlation analysis. Table 6 summarizes the results of the ANOVA.

\section{Tables 5 and 6 about here}

\section{Conclusion and limitations}

While the clear association between a Vincentian marketing orientation and strong social performance is not surprising, it reinforces the notion that just as marketing is central to the success of for-profit businesses (Liu, 2012), so, too, is it a driver of performance in social enterprises. Further, in this context, a Vincentian marketing orientation not only serves social enterprises' social objectives but also their financial and environmental ones. Hence, maintaining a balance between competing objectives is assisted through the adoption of a 
Vincentian marketing orientation, highlighting the emphasis on the beneficiary, social welfare, and the underlying business or commercial needs of financial performance.

Interestingly, while items such as seeking feedback from both beneficiaries and stakeholders (Items 3 and 4 in Table 1) and communicating this feedback throughout the social enterprise (Item 10 in Table 1) were strongly associated with a Vincentian marketing orientation, investing significantly in marketing and promotion (Item 18 in Table 1) was not considered important. With a mean of less than three, this finding reinforces the notion that a Vincentian marketing orientation does not require significant financial investment for social enterprises. Instead, it highlights the importance of a marketing orientation focused on the needs of the poor rather than self-promotion of the organization and is an important insight for organizations whose resources (particularly financial) are often limited. Hence, unlike in the case of for-profit firms seeking growth through promotion of their products and services, it seems social enterprises' marketing efforts are better rewarded through investing time in understanding the needs of beneficiaries and other stakeholders, rather than investing limited funds on promotional activity. This is perhaps consistent with the notion that social enterprises are commonly established with a clear social objective and acutely aware of the social need to be addressed within their target markets. Hence, such organizations are not necessarily working to attract a customer base but toward achieving a solution for those in need - an identified customer base. Since the completion of the study, these findings have been communicated to social enterprise managers during discussions with the authors and were useful to SE managers in more effectively and efficiently achieving their social mission.

The results also highlighted the importance of a long-term value orientation to social enterprises. This orientation means that social enterprises focus on practices that will ensure the sustainability of their organization, such as ethical principles, spill-over effects of benefits, training for beneficiaries, and empathy. A long-term value orientation was more 
visible in firms with a $\mathrm{VMO}$, indicating that these organizations are better equipped to deal with a variety of interests and balance competing short- and long-term priorities (RidleyDuff, 2008). Similarly, it was important to not only the social success of these organizations, but also the economic and environmental success. Sullivan Mort, Weerawardena, and Carnegie (2003) explain that it is important for non-profits such as social enterprises to ensure that their social and economic value creating activities contribute to the long-term viability of the organization while maintaining their social mission as central. It is this concept that these long-term value orientation measures, and these results, confirm this argument for better performing organizations.

The present study has two limitations affecting validity and generalizability. First, the study's small number of usable responses limited validity assessments for the instruments. In addition, the sampling was a non-random judgement sample of social enterprises known by the authors or based upon publically available information. Second, the survey was administered in Australia where the economic conditions are not as depressed as in some other developed nations. Notwithstanding these limitations, the findings provide important preliminary insights into the value of a Vincentian marketing orientation not only from a social perspective but also from a financial and environmental perspective. The present study suggests that social enterprise managers should consider developing more of a Vincentian marketing orientation to better serve their beneficiaries and enhance economic viability. 


\section{Bibliography}

Avlonitis, G.J. and Gounaris, S.P. (1997). Market orientation and company performance: Industrial vs. consumer goods companies. Industrial Marketing Management 26(5), 385-402.

Balabanis, G., Stables, R.E. and Phillips, H.C. (1997). Market orientation in the top 200 British charity organizations and its impact on their performance. European Journal of Marketing 31(8), 583-603.

Barman, E. (2007). What is the bottom line for nonprofit organizations? A history of measurement in the British voluntary sector. Voluntas 18, 101-115.

Barraket, J., Collyer, N., O'Connor, M. and Anderson, H. (2010). Finding Australia's social enterprise sector: Final report. Queensland University of Technology and Social Traders, Brisbane, Australia.

Bennett, R. (2008). Marketing of voluntary organizations as contract providers of national and local government welfare services in the UK. Voluntas 19, 268-295.

Bergkvist, L. and Rossiter, J.R. (2007). The predictive validity of multiple-item versus single-item measures of the same constructs. Journal of Marketing Research 36, 175 184.

Borch, F.J. (1957). The marketing philosophy as a way of business life. New York, General Electric.

Bowes, J.C. (1998). St. Vincent de Paul and business ethics. Journal of Business Ethics 17(15), 1663-1667.

Cornelius, N., Todres, M., Janjuha-Jivraj, S., Woods, A. and Wallace, J. (2007). Corporate social responsibility and the social enterprise. Journal of Business Ethics 81, 355-370.

Darroch, J., Miles, M.P., Jardine, A. and Cooke, E.F. (2004). The 2004 AMA definition of marketing and its relationship to a market orientation: An extension of Cooke, Rayburn, \& Abercrome (1992). Journal of Marketing Theory and Practice 12(4), 2938.

Eversole, R. and Eastley, K. (2011). Tasmanian social enterprise study: Baseline study report. The Institute for Regional Development, Cradle Coast, Australia.

Flanagan, P., M. Fleckenstein, P.D. Primeaux, V. Schoaf, and P. Werhane. (2008). Introduction: The wide reach of business ethics. Journal of Business Ethics 84, 1-2.

Felton, A.P. (1959). Making the marketing concept work. Harvard Business Review 37, 55 65.

Ferrari, J.R. and Cowman, S.E. (2004). Toward a reliable and valid measure of institutional mission and values perception: The DePaul values inventory. Journal of Beliefs \& Values: Studies in Religion \& Education 2, 43-54. 
Flanagan, P., Fleckenstein, M., Primeaux, P.D., Schoaf, V. and Werhane, P. (2008). Introduction: The wide reach of business ethics. Journal of Business Ethics 84, 1-2.

Foxall, G. (1984). Corporate innovation: Marketing and strategy. New York, St. Martin's Press.

Hair, J.F., Anderson, R.E., Tatham, R.L. and Black, W.C. (1998). Multivariate data analysis. Englewood Cliffs, NJ, Prentice Hall.

Gainer, B. and Padanyi, P. (2002). Applying the marketing concept to cultural organisations: An empirical study of the relationship between marketing orientation and performance. International Journal of Nonprofit and Voluntary Sector Marketing 7(2), 182-193.

Jaworski, B.J. and Kohli, A.K. (1993). Market orientation: Antecedents and consequences. Journal of Marketing 57(July), 53-70.

Kara, A., Spillan, J.E. and DeShields, O.W., Jr. (2004). An empirical investigation of the link between market orientation and business performance in non-profit service providers. Journal of Marketing Theory and Practice 12(2), 59-72.

Keith, R.J. (1959). An interpretation of the marketing concept, In Advancing Marketing Efficiency, Proceedings of the forty-first National Conference. Chicago, American Marketing Association.

Keith, R.J. (1960). The marketing revolution. Journal of Marketing 24, 35-38.

Kerlin, J.A. (2006). Social enterprise in the United States and Europe: Understanding and learning from the differences. Voluntas 17, 247-263.

Kirca, A.H., Jayachandran, S. and Bearden, W.O. (2005). Market orientation: A metaanalytic review and assessment of its antecedents and impact on performance. Journal of Marketing 69(2), 24-41.

Kohli, A.K., Jaworski, B.J. and Kumar, A. (1993). MARKOR: A measure of marketing orientation. Journal of Marketing Research 30, 467-477.

Kotler, P. and Levy, S.J. (1969). Broadening the concept of marketing. Journal of Marketing $33,10-15$.

Lazer, W. (1969). Marketing's changing social relationships. Journal of Marketing, 33, 3-9.

Liu, G. (2012). Impacts of instrumental versus relational centered logic on cause-related marketing decision making. Journal of Business Ethics DOI: 10.1007/s10551-0121292-8, 21 pages.

Maignan, I. and Ferrell, O.C. (2004). Corporate social responsibility and marketing: An integrated framework. Journal of the Academy of Marketing Sciences 32(1), 3-19. 
McKenna, T. F. (1997). Vincent de Paul: A saint who got his worlds together. Journal of Business Ethics 16, 299 - 307.

Miles, M.P. and Arnold, D.R. (1991). The relationship between marketing orientation and entrepreneurial orientation. Entrepreneurship Theory and Practice 15 (4), 49-65.

Miles, M.P., Verreynne, M., Luke, B., Eversole, R., and Barraket, J. (Forthcoming). The relationship of entrepreneurial orientation, Vincentian values and economic and social performance in social enterprises. Review of Business.

Mish, J. and Scammon, D.L. (2010). Principle-based stakeholder marketing: Insights from private triple-bottom-line firms. Journal of Public Policy \& Marketing 29 (1), 12-26.

Moss-Kanter, R. and Summers, D.V. (2001). Doing well while doing good: Dilemmas of performance measurement in nonprofit organizations and the need for a multipleconstituency approach, in McKevitt, D. and Lawton, A. Public Sector Management: Theory, critique \& practice. Sage: London. (220-236).

Mottner, S. and Ford, J.B. (2005). Measuring non-profit marketing strategy performance: The case of museum stores. Journal of Business Research 58, 829-840.

Nicholls, A. (2009). 'We do good things, don't we?': Blended value accounting in social entrepreneurship. Accounting, Organizations and Society 34, 755-769.

Nicholls, A. (2010). The legitimacy of social entrepreneurship: Reflexive isomorphism in a pre-paradigmatic field. Entrepreneurship Theory and Practice 34, 611-633.

Nunnally, J.C. (1978). Psychometric Theory, (2 $2^{\text {nd }}$ ed.). New York, McGraw-Hill.

Perreault, W.D., Cannon, J. and McCarthy, E. (2008). Basic marketing. Columbus, OH, McGraw-Hill.

Placet, M., Anderson, R. and Fowler, K.M. (2005). Strategies for Sustainability. Research Technology Management 48(5), 32-41.

Polonsky, M.J. (2011). Transformative green marketing: Impediments and opportunities. Journal of Business Research 64, 1311-1319.

Ridley-Duff, R. (2008). Social enterprise as a socially rational business. International Journal of Entrepreneurial Behaviour \& Research 14(5), 291 - 312.

St. Vincent de Paul Society. (2004). The Ethos of the St. Vincent de Paul Society in Australia. Lewisham, Australia, St. Vincent de Paul Society NSW/ACT Community and Corporate Relations Team.

Sheth, J.N. and Uslay, C. (2007). Implication of the revised definition of marketing: From exchange to value creation. Journal of Public Policy \& Marketing 26(2), 302-307.

Shaw, E. (2004). Marketing in the social enterprise context: Is it entrepreneurial? Qualitative Market Research 7(3), 194-205. 
Sullivan Mort, G., Weerawardena, J. and Carnegie, K. (2003). Social entrepreneurship: Towards conceptualisation. International Journal of Nonprofit and Voluntary Sector Marketing 8 (1), 76-88.

Vazquez, R., Alvarez, L.I. and Santos, M.L. (2002). Market orientation and social services in private non-profit organizations. European Journal of Marketing 36(9/10), 1022-1046.

Zhou, Y., Chao, P. and Huang, G. (2009). Modelling market orientation and organizational antecedents in a social marketing context: Evidence from China. International Marketing Review 26(3), 256-274. 


\section{Table 1}

\section{Vincentian Marketing Orientation Scale}

\begin{tabular}{|c|c|c|c|}
\hline & Mean & Std. Deviation & $\mathbf{N}$ \\
\hline $\begin{array}{l}\text { Marketing Generation Sub-scale }^{1} \\
\text { 1. We regularly meet with our beneficiaries and stakeholders to better } \\
\text { understand their needs. }\end{array}$ & 3.93 & .728 & 44 \\
\hline $\begin{array}{l}\text { 2. We understand the functions and responsibilities of social enterprises } \\
\text { in the current economic and political environment. }\end{array}$ & 3.98 & .849 & 44 \\
\hline $\begin{array}{l}\text { 3. We seek and obtain feedback on our beneficiaries' levels of } \\
\text { satisfaction on a regular basis. }\end{array}$ & 3.84 & .805 & 44 \\
\hline $\begin{array}{l}\text { 4. We seek and obtain feedback on our stakeholders' levels of } \\
\text { satisfaction on a regular basis. }\end{array}$ & 4.00 & .778 & 44 \\
\hline 5. We have multiple ways to get feedback from our beneficiaries. & 3.73 & .694 & 44 \\
\hline $\begin{array}{l}\text { 6. We monitor how changes in the economy, technology, and } \\
\text { regulations may impact us. }\end{array}$ & 3.82 & .843 & 44 \\
\hline $\begin{array}{l}\text { 7. We regularly compare how we think we are performing with how our } \\
\text { stakeholders perceive we are performing. }\end{array}$ & 3.70 & .851 & 44 \\
\hline $\begin{array}{l}\text { 8. We regularly examine the factors that influence our beneficiaries' } \\
\text { decision to seek our assistance. }\end{array}$ & 3.59 & .787 & 44 \\
\hline Marketing Dissemination Sub-scale ${ }^{1}$ & & & \\
\hline 9. We share information and cooperate with other similar organizations. & 4.16 & .568 & 44 \\
\hline $\begin{array}{l}\text { 10. We communicate beneficiary and stakeholder feedback throughout } \\
\text { the entire organization. }\end{array}$ & 3.70 & .878 & 44 \\
\hline $\begin{array}{l}\text { 11. We have regular organizational conversations to communicate } \\
\text { important operational and strategic changes. }\end{array}$ & 3.84 & .776 & 44 \\
\hline $\begin{array}{l}\text { 12. We have a business model that is understood by our employees and } \\
\text { stakeholders. } \\
\text { Marketing Responsiveness Sub-scale }^{1}\end{array}$ & 3.84 & .745 & 44 \\
\hline $\begin{array}{l}\text { 13. We have sufficient information available to modify and develop } \\
\text { appropriate services for our beneficiaries. }\end{array}$ & 3.64 & .810 & 44 \\
\hline $\begin{array}{l}\text { 14. We use all information at our disposal to modify and develop } \\
\text { services for our beneficiaries. }\end{array}$ & 4.00 & .807 & 44 \\
\hline 15. We attempt to respond to emerging beneficiary or stakeholder needs. & 4.09 & .603 & 44 \\
\hline 16. We are flexible in strategy and adapt our strategies as needs change. & 4.14 & .594 & 44 \\
\hline 17. We attempt to differentiate our services from other alternatives. & 3.75 & .866 & 44 \\
\hline 18. We invest significantly in marketing and promotion. & 2.89 & 1.017 & 44 \\
\hline
\end{tabular}

1: Adapted from Jaworski and Kohli (1993); Kara et al. (2004); Kolhi et al. (1993); Vazquez et al. (2002); and Zhou et al. (2009) 
Table 2

\section{Item Statistics}

\begin{tabular}{|c|c|c|c|}
\hline & Mean & $\begin{array}{c}\text { Std. } \\
\text { Deviation }\end{array}$ & $\mathrm{N}$ \\
\hline We operate our organization in an environmentally sustainable manner. & 3.86 & .804 & 43 \\
\hline Our donors are very satisfied with us. & 3.70 & .741 & 43 \\
\hline Our organization operates in a socially sustainable manner. & 4.58 & .545 & 43 \\
\hline We help inform the community about the plight of our beneficiaries. & 3.74 & .848 & 43 \\
\hline We help mobilise interest for additional social welfare initiatives. & 3.63 & .874 & 43 \\
\hline We are often perceived and valued by our beneficiaries as a provider of last resort. & 2.70 & 1.059 & 43 \\
\hline In the past few years we have met our objectives in terms of beneficiaries served. & 3.88 & 697 & 43 \\
\hline Beneficiaries are satisfied with our services. & 4.09 & .610 & 43 \\
\hline Beneficiaries and stakeholders recommend our services to others. & 4.02 & .597 & 43 \\
\hline
\end{tabular}


Table 3

\section{Economic Performance Scale}

Item Statistics

\begin{tabular}{|c|c|c|c|}
\hline & Mean & $\begin{array}{c}\text { Std. } \\
\text { Deviation }\end{array}$ & $\mathrm{N}$ \\
\hline We are more effective in serving our beneficiaries than others. & 3.56 & .796 & 48 \\
\hline In the past few years, we have increased our effectiveness. & 4.13 & .606 & 48 \\
\hline We are more efficient in serving our beneficiaries than others. & 3.50 & .744 & 48 \\
\hline In the past few years, we have increase our efficiency. & 4.17 & 630 & 48 \\
\hline In the past few years, our financial situation has improved. & 3.38 & 1.214 & 48 \\
\hline Our organization is financially sustainable. & 3.69 & .993 & 48 \\
\hline
\end{tabular}


Table 4

\section{Vincentian Long-term Value Creation Scale}

\begin{tabular}{|c|c|c|c|}
\hline & Mean & Std. Deviation & $\mathbf{N}$ \\
\hline Our strategy is driven by our ethical and moral principles. & 4.50 & .587 & 46 \\
\hline $\begin{array}{l}\text { When evaluating a new proposal we consider if the beneficiaries can be } \\
\text { involved in helping themselves and others. }\end{array}$ & 3.87 & .859 & 46 \\
\hline $\begin{array}{l}\text { We focus on meeting the needs of the disadvantaged through education } \\
\text { and training. }\end{array}$ & 4.15 & .842 & 46 \\
\hline $\begin{array}{l}\text { When evaluating a proposal we consider if it promotes equity and } \\
\text { justice. }\end{array}$ & 4.48 & .623 & 46 \\
\hline We have empathy for those who are suffering or disadvantaged & 3.72 & .886 & 46 \\
\hline
\end{tabular}


Table 5

\section{Correlations Between Focus On Needy; Economic, Social and Environmental Performance; Long-Term Value Performance and Vincentian Marketing Orientation}

\begin{tabular}{|c|c|c|c|c|c|c|c|c|}
\hline & $\begin{array}{l}\text { Mean } \\
\mathrm{s}\end{array}$ & $\begin{array}{c}\text { S.D } \\
\text {. }\end{array}$ & $\begin{array}{l}\text { Meet } \\
\text { Needs }\end{array}$ & $\mathrm{MO}$ & $\begin{array}{l}\text { Long- } \\
\text { term } \\
\text { value }\end{array}$ & $\begin{array}{c}\text { Social } \\
\text { performance }\end{array}$ & $\begin{array}{c}\text { Economic } \\
\text { performance }\end{array}$ & $\begin{array}{c}\text { Environ- } \\
\text { mental } \\
\text { performance }\end{array}$ \\
\hline Meet needs & & & 1 & $.492^{* *}$ & $.356^{*}$ & $.376^{*}$ & .014 & .174 \\
\hline $\mathrm{MO}$ & & & $.492^{* * *}$ & 1 & $.672^{* * *}$ & $.659^{* * *}$ & $.334^{*}$ & $.368^{*}$ \\
\hline $\begin{array}{l}\text { Long-term } \\
\text { value }\end{array}$ & & & $.356^{*}$ & $.672^{* * *}$ & 1 & $.672^{\text {*** }}$ & .084 & .259 \\
\hline $\begin{array}{l}\text { Social } \\
\text { performance }\end{array}$ & & & $.376^{*}$ & $.659^{* *}$ & $.672^{* *}$ & 1 & .181 & $.304^{*}$ \\
\hline $\begin{array}{l}\text { Economic } \\
\text { performance }\end{array}$ & & & .014 & $.334^{*}$ & .084 & .181 & 1 & .074 \\
\hline $\begin{array}{l}\text { Environmental } \\
\text { performance }\end{array}$ & & & .174 & $.368^{*}$ & .259 & $.304^{*}$ & .074 & 1 \\
\hline
\end{tabular}

**. Correlation is significant at the 0.01 level (2-tailed).

*. Correlation is significant at the 0.05 level (2-tailed). 
Table 6

\section{ANOVA: differences between high and low MO firms}

\begin{tabular}{|c|c|c|c|c|c|c|}
\hline \multicolumn{7}{|c|}{ ANOVA } \\
\hline & & $\begin{array}{l}\text { Sum of } \\
\text { Squares }\end{array}$ & df & $\begin{array}{r}\text { Mean } \\
\text { Square }\end{array}$ & $\bar{F}$ & Sig. \\
\hline \multirow{3}{*}{$\begin{array}{l}\text { Social } \\
\text { performance }\end{array}$} & Between Groups & 1.550 & 1 & 1.550 & 8.535 & .006 \\
\hline & Within Groups & 6.902 & 38 & .182 & & \\
\hline & Total & 8.453 & 39 & & & \\
\hline \multirow{3}{*}{$\begin{array}{l}\text { Economic } \\
\text { performance }\end{array}$} & Between Groups & 1.318 & 1 & 1.318 & 5.397 & .025 \\
\hline & Within Groups & 10.253 & 42 & .244 & & \\
\hline & Total & 11.571 & 43 & & & \\
\hline \multirow{3}{*}{$\begin{array}{l}\text { Environmental } \\
\text { performance }\end{array}$} & Between Groups & 6.096 & 1 & 6.096 & 12.242 & .001 \\
\hline & Within Groups & 20.416 & 41 & .498 & & \\
\hline & Total & 26.512 & 42 & & & \\
\hline \multirow[t]{3}{*}{ Meet needs } & Between Groups & 5.764 & 1 & 5.764 & 10.027 & .003 \\
\hline & Within Groups & 24.145 & 42 & .575 & & \\
\hline & Total & 29.909 & 43 & & & \\
\hline \multirow[t]{3}{*}{ Long-term value } & Between Groups & 3.180 & 1 & 3.180 & 14.059 & .001 \\
\hline & Within Groups & 9.046 & 40 & .226 & & \\
\hline & Total & 12.226 & 41 & & & \\
\hline
\end{tabular}

